\title{
LAND COVER DYNAMICS AND LANDSCAPE STRUCTURE IN THE AREA SURROUNDING WATER RESERVOIRS, MOUNTAINOUS REGION OF RIO DE JANEIRO
}

\author{
Lucas de Siqueira Cardinelli ${ }^{1 *}$, José Marinaldo Gleriani², Sebastião Venâncio Martins ${ }^{3}$
}

\author{
${ }^{1 *}$ Universidade Estadual de Campinas, Instituto de Biologia, Campinas, SP, Brasil - email: lucasscardinelli@ hotmail.com \\ ${ }^{2}$ Universidade Federal de Viçosa, Departamento de Engenharia Florestal, Viçosa, MG, Brasil - email: gleriani@ gmail.com \\ ${ }^{3}$ Universidade Federal de Viçosa, Departamento de Engenharia Florestal, Viçosa, MG, Brasil - email: venancioufv@gmail.com
}

Received for publication: 09/04/2019 - Accepted for publication: 02/06/2020

\begin{abstract}
Resumo
Dinâmica de cobertura da terra e estrutura da paisagem no entorno de reservatórios hídricos, região serrana do Rio de Janeiro. Objetivou-se avaliar a dinâmica de cobertura da terra e a estrutura da paisagem no entorno de um conjunto de reservatórios de usinas hidroelétricas construídas em 2009 na região serrana do Rio de Janeiro. A análise foi feita através da interpretação de imagens orbitais multiespectrais da série Landsat de 2003, 2009 e 2013, considerando as seguintes classes: floresta em estágio inicial de sucessão, floresta em estágio médio de sucessão, pasto limpo, pasto sujo, afloramento rochoso, cidade e água. Os mapas temáticos foram utilizados para calcular métricas de área e proximidade na seção da bacia hidrográfica e na Área de Preservação Permanente (APP) dos reservatórios. A classe predominante é o pasto limpo, consequência da pecuária extensiva praticada na microbacia. A cobertura florestal se manteve estável no período avaliado, embora apresentando-se bastante fragmentada com muitos fragmentos pequenos em estágio médio de sucessão. Em média, estas florestas apresentaramáreas três vezes maiores que as florestas em estágio inicial de sucessão, sem mudanças significativas no tamanho e no grau de isolamento de ambas no período avaliado. Houve redução da cobertura florestal das APP's no período anterior à construção das barragens. Por outro lado, de 2009 a 2013, após cercamento das áreas, houve um aumento de 35\% na cobertura florestal das APP's via regeneração natural assistida, sugerindo que a região apresenta alto potencial para restauração com baixo custo.

Palavras-chave: ecologia da paisagem, restauração ecológica, matas ciliares, Área de Preservação Permanente, regeneração natural assistida
\end{abstract}

\begin{abstract}
The aim of this study is to evaluate land cover dynamics and landscape structure in the area surrounding two water reservoirs built-in 2009 for energy production, in the mountainous region of the State of Rio de Janeiro (Serra Fluminense). The analysis was developed through the interpretation of Landsat images from 2003, 2009, and 2013, considering the following land cover classes: early successional forest, mid successional forest, pasture, pasture with shrubs and trees, geological outcrop, urban area, and water area. We used thematic maps to determine landscape metrics of size and proximity in the reservoirs catchment area and the Permanent Preservation Area (PPA). At catchment level, pasture was predominant, a consequence of the extensive livestock production carried out in the whole watershed. During the evaluated period, the forest area remained consistent, however, fragmented in many small patches of mid successional forest. The average patch area of mid successional forest is three times the size of the early successional forest patches. For neither forest land cover classes, no significant variations through time in area or isolation were identified. On the PPA, an overall reduction of the forest cover was registered before the construction of the reservoir. However, from 2009 to 2013, after the enclosure of PPA areas, the forest cover increased 35\% via assisted natural regeneration, suggesting a high potential for cost-effective restoration in the region.
\end{abstract}

Keywords: landscape ecology, ecological restoration, riparian forest, Permanent Preservation Area, assisted natural regeneration

\section{INTRODUCTION}

In the last two decades, forest restoration has expanded its area of operation from local to larger landscapescale projects (METZGER; BRANCALION, 2013), which constitutes an improvement in natural resources management. Joly et al. (2014) call for the development of large scale conservation and restoration programs, with landscape ecology as a management tool. Holl and Aide (2011) highlight that considering the landscape scale in a restoration project can favor the use of less costly restoration methods such as assisted natural regeneration and nucleation.

Landscape ecology studies the effects of spatial patterns on ecological processes, addressing issues such as connectivity, isolation, and vegetation cover in the landscape, which significantly impact the natural regeneration potential of any given area (LEITE et al., 2013; TAMBOSI et al., 2014). According to Tambosi $e t$ al. (2014), landscapes with intermediate resilience are priority areas for ecological restoration, as they present the

FLORESTA, Curitiba, PR, v. 50, n. 4, p. 1808 - 1817, out/dez 2020.

Cardinelli, L. S. et.al.

ISSN eletrônico 1982-4688

1808

DOI: $10.5380 /$ rf.v50 i4. 65893 
highest potential and better cost/benefit ratio, i.e., higher environmental net gains for less financial resources spent. Magnago et al. (2015) and Martensen et al. (2012) established that areas where forest cover is below 30\%, are close to the fragmentation threshold, below which the loss of biodiversity is accentuated.

About $29 \%$ of the Grande river watershed, part of the Paraíba do Sul river basin, in the State of Rio de Janeiro, is covered by forest which is in fragile environmental condition with a high risk of erosion, due to the anthropogenic impacts, according to the Basic Sanitation Plan of Santa Maria Madalena municipality, State of Rio de Janeiro (DRZ GEOTECHNOLOGY AND CONSULTING, 2012). In 2009, in order to harness the regional hydroelectric potential, the construction of three Small Hydroelectric Plants (SHPs) in the Rio Grande was initiated. The undertaking has caused changes in the landscape, both directly, by the damming of the waterways and consequent creation of water reservoirs, and indirectly, by the infrastructure associated with construction and operation. Among the main environmental impacts of the SHPs are the increase of flooded areas and the reduction and relocation of the Permanent Preservation Area (PPA) and riparian forest, which hinders the regional spatial pattern of forest cover.

Remote sensing techniques in environmental studies, namely the processing and interpretation of satellite images, serves as a tool to assess the evolution of forest cover in a region (ARROYO-MORA et al., 2005; MARTINS et al., 2014; REZENDE et al., 2015; SANTOS et al., 2012). The knowledge on land use and land cover dynamics improves the diagnosis of the landscape resilience potential and helps to develop sustainable strategies to mitigate the impacts of human activities (HOLL; AIDE, 2011; LEITE et al., 2013; METZGER; BRANCALION, 2013). Thus, the objective of this study is to evaluate land use and land cover dynamics and landscape structure around a set of water reservoirs created by hydroelectric power plants in the mountainous region of the State of Rio de Janeiro. Although the predominance of agricultural activities in the region has already greatly modified the original landscape cover, this work hypothesizes that the studied catchment still presents high natural regeneration potential, due to favorable environmental characteristics in the mountainous region of Rio de Janeiro.

\section{MATERIAL AND METHODS}

\section{Study area}

The study was developed in the catchment (11 636 ha) supplying the water reservoirs of Cajú and São Sebastião do Alto SHPs, located on the Grande river, a large right-bank tributary of Paraíba do Sul river. The water reservoirs are located on the border between the municipalities of Santa Maria Madalena and São Sebastião do Alto, in the northern mountainous region of Rio de Janeiro State, Brazil (Figure 1). Santo Antônio SHP, also located in Grande river, in the municipality of Bom Jardim, RJ, was not included in this study, due to the distance from the other two SHPs.

The terrain is mountainous to strong undulating (ALVARES et al., 2013), and the average elevation in the watershed is 370 meters asml (maximum $1125 \mathrm{~m}$, minimum $115 \mathrm{~m}$ ), values acquired from the Digital Elevation Model of the State of Rio de Janeiro. Climate is Aw (Tropical, with dry winter) following the Köppen classification, with an average annual temperature of $21.5^{\circ} \mathrm{C}$ and annual precipitation of $1328 \mathrm{~mm}$ (ALVARES et al., 2013). The soil falls mostly on the eutrophic Red Argisol and Red-Yellow Argisol classes (DRZ GEOTECNOLOGIA E CONSULTORIA, 2012; PROJETO RADAMBRASIL, 1983). The study area is located on the transition between two large forest formations in the Atlantic Forest domain, the Dense Ombrophylous Forest, and the Semideciduous Seasonal Forest (RADAMBRASIL PROJECT, 1983).

In 2011, two years after the beginning of the construction, the responsible company started a large program of forest restoration in the Permanent Preservation Area (PPA) of the Cajú and São Sebastião do Alto SHP reservoirs. The project included reforestation with regional native species, in some parts of the PPA, and the isolation of the significant degradation factors such as fire and soil compression by cattle production, through the construction of firebreaks and enclosure of the PPA perimeter. 


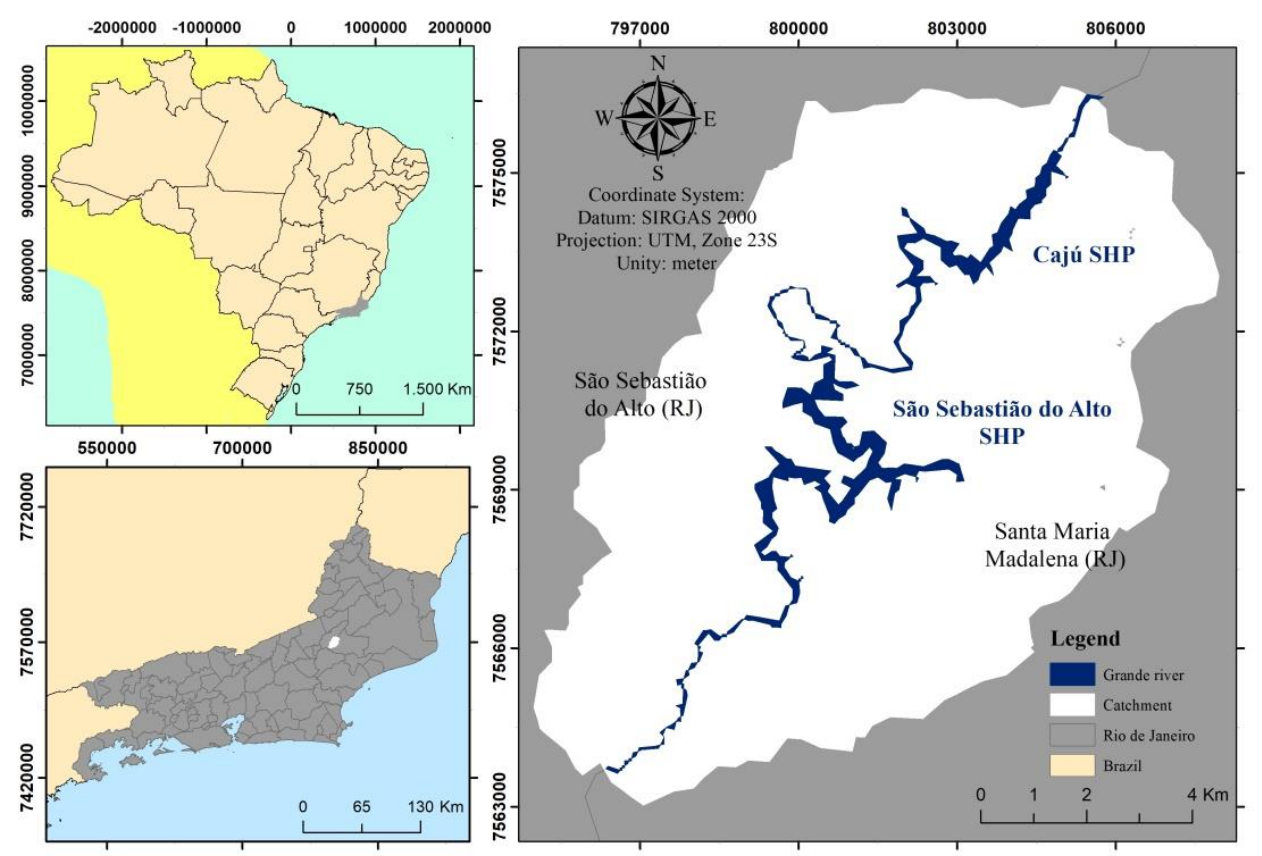

Figure 1. Location of the study area.

Figura 1. Localização da área de estudo.

\section{Image processing and photointerpretation}

Images available in USGS (https://earthexplorer.usgs.gov) of the ETM+/Landsat-7 (February 13 and April 18, 2003), TM/Landsat-5 (May 28, 2009) and OLI/Landsat-8 sensors (October 14, 2013), from orbit/point $216 / 75$, with $30 \mathrm{~m}$ spatial resolution, geometric correction and orthorectified were used in this study. For the year 2003 , two scenes were processed in order to remove the cloud cover and shadowing. The dates were selected to evaluate variations in land use and landscape structure in the period between the years before (2003), during (2009), and after (2013) the construction of the SHPs. All the scenes were in the UTM/WGS84 projection and were georeferenced to the UTM/SIRGAS2000 projection. The interpreted area was constricted to the catchment of the two reservoirs, using the topographic map 1:50,000 SF-23-X-D-VI-4 available in IBGE (https://biblioteca.ibge.gov.br).

Segmentation, in order to avoid manual digitalization of polygons, and the photointerpretation of the scenes were carried out with Spring software. However, the digital classification proved ineffective, mainly due to topographic shading and the presence of clouds. Therefore, a visual interpretation was performed based on the color and texture of the features, confirmed through field reambulation. To facilitate the photointerpretation and to better discriminate size and density of the phytomass, the Normalized Difference Vegetation Index (NDVI) was generated according to the equation:

$$
N D V I=\frac{N I R-R}{N I R+R}
$$

where NIR (Reflectance in the near-infrared band) is the digital reflectance value for sensor bands 4 and 3 of TM and ETM+ (near-infrared band), and R (Reflectance in the red band) is the digital reflectance value for sensor bands 5 and 4 of OLI (red band). The 3(B)NDVI(G)5(R) for the TM and ETM+ sensor data and 4(B)NDVI(G)6(R) for the OLI sensor were used as the color compositions. Since the images are Land Surface Reflectance type, the atmospheric correction for the photointerpretation procedure was not required (SONG et al., 2001). The interpretation was performed considering the following land cover classes:

- Mid successional forest (MSF): area with continuous arboreal vegetation cover, with some emerging trees larger and more diverse than early successional forest;

- Early successional forest (ESF): area with lower tree cover, with the predominance of pioneer species and, generally with vines; 
- Pasture with shrubs and trees (PST): area with predominantly herbaceous vegetation cover, with some shrubs and trees, sparsely distributed;

- Pasture (P): area with clear herbaceous vegetation predominance;

- Geological outcrop (GO): area with exposed bedrock possibly colonized by pioneer vegetation;

- Urban area (UA): urbanized area associated with human occupation;

- Water area (WA): rivers and water reservoirs.

Subsequently, global accuracy was achieved (GONGALTON; GREEN, 2009) through a sample of 292 points, whose uncertainties, when present, were checked during fieldwork. The establishment of an interpretation key helped the interpretation of previous years.

The images were then exported in the ASCII format (American Standard Code for Information Interchange), to calculate landscape metrics and converted to shapefile format for cartography and spatial analysis using ArcGIS 10.4.1 software.

\section{Landscape structure}

The characterization of landscape structure in the three years was achieved by calculating the metrics of the number of patches (NP), patch area (PA), largest forest patch index (LFPI), and nearest-neighbor distance (NND), using Fragstats 4.2.1 software. A value of 8 pixels was considered as the neighbor rule, which ponders all adjacent cells (including the diagonals) as possible neighbors of a given pixel. For patch-level metrics, only MSF and ESF patches greater than or equal to 1 ha were considered, and classified by number count and area of and distributed by frequency among size classes.

The null hypothesis of parity in the forest classes (MSF and ESF) between the years for patch area (PA) and nearest neighbor distance (NND) metrics was tested for 5\% significance following the Kruskal-Wallis analysis. This is a non-parametric analysis alternative to ANOVA suitable for data that do not follow a normal distribution, as examined through the Shapiro-Wilk normality test. In addition, the hypothesis of equality between the two forest classes (MSF and ESF) was tested following the Wilcoxon test for two samples for the patch area values (PA) for each year (at 5\% significance). The analyses were performed in the R software using the functions "shapiro.test", "kruskal.test" and "wilcox.test".

\section{Spatial analysis}

The approximate areas of land cover classes in the PPA for each year were calculated using the overlap and proximity operators of the ArcGIS Spatial Analysis package. For the years 2003 and 2009, the PPA was defined around the river banks, resulting in a protected area $50 \mathrm{~m}$ from each side of the streambed, following the 1965 Forest Code (BRASIL, 1965). In 2013, the PPA of the water reservoirs was reconsidered for electricity generation, resulting in a protected area at least $30 \mathrm{~m}$ wide from the reservoirs Full Supply Level, following the Native Vegetation Protection Law, also known as the New Forest Code of 2012 (BRASIL, 2012).

The protection effectiveness in the PPAs was evaluated throughout the historical image series, through the differences between the areas between the years of 2013, 2009 and 2003. Also, the flooded areas for each class (during construction) NN were estimated by subtracting the water areas in 2009 from the ones in 2013.

\section{RESULTS}

\section{Watershed}

The overall accuracy, evaluated with the error matrix, was above $98 \%$ in the three years, indicating that the classification of the land use and cover was adequate (GONGALTON; GREEN, 2009).

The predominant class throughout the years is consistently the pasture, occupying over $50 \%$ of the landscape (Figure 2, Table 1). The class pasture with shrubs and trees had a significant variation over the years, with a reduction in its coverage from 2003 to 2009, and a considerable increase in 2013. After the construction of the water reservoirs, water coverage in 2013 increased three-fold compared to the baseline situation (in 2003). The urban areas and outcrop classes did not change significantly in this 10-year interval. 

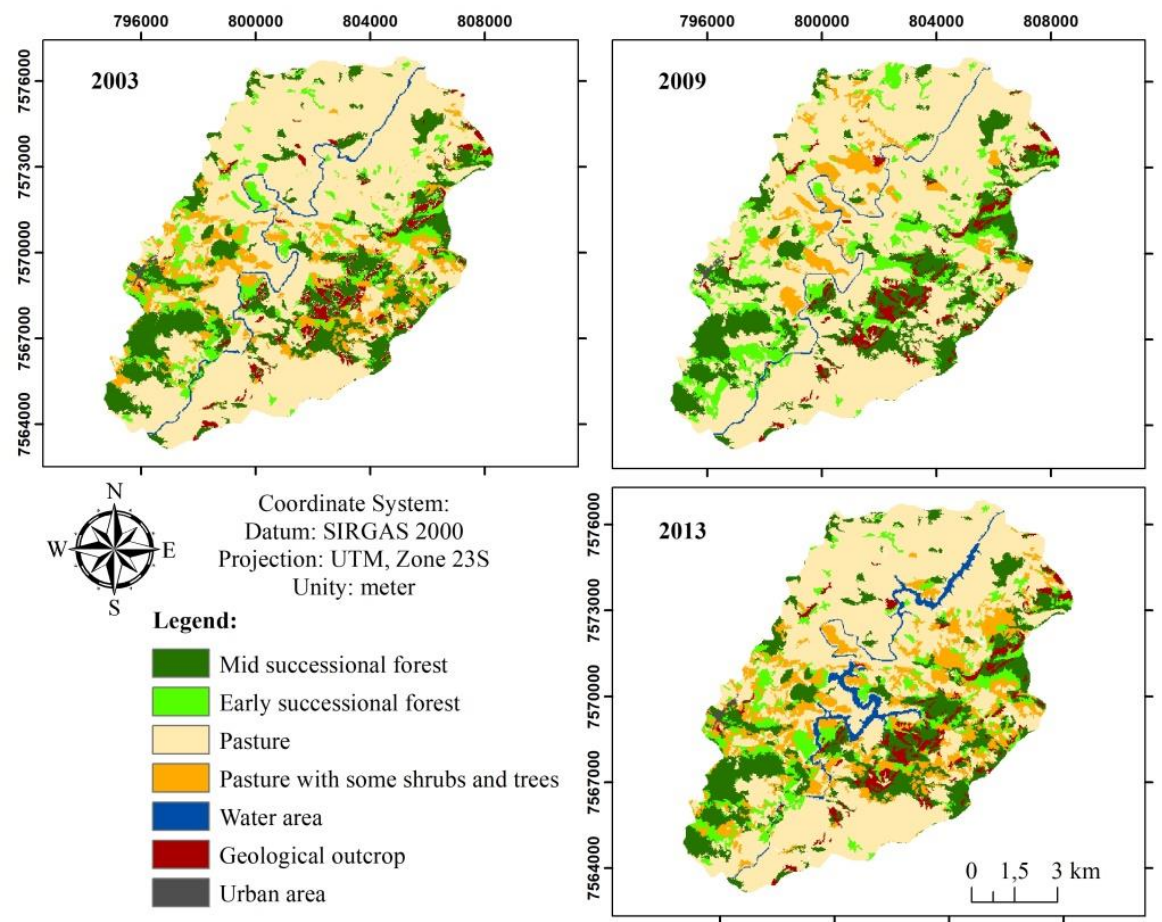

Figure 2. Land cover of the catchment of Cajú and São Sebastião do Alto SHPs, in the mountainous region of the State of Rio de Janeiro in the years 2003, 2009, and 2013.

Figura 2. Mapas de cobertura da terra da microbacia hidrográfica das PCH's Cajú e São Sebastião do Alto, na região serrana do estado do Rio de Janeiro, para os anos 2003, 2009 e 2013.

Table 1. Total area (ha and \%) for each land cover class in the catchment of Cajú and São Sebastião do Alto SHPs, in the mountainous region of the State of Rio de Janeiro in the years 2003, 2009 and 2013.

Tabela 1. Área (ha) e proporção $(\%)$ de cada classe de cobertura da terra em relação à área total da microbacia hidrográfica das PCH's Cajú e São Sebastião do Alto, na região serrana do estado do Rio de Janeiro, para os anos de 2003, 2009 e 2013.

\begin{tabular}{ccccccc}
\hline & \multicolumn{2}{c}{$\mathbf{2 0 0 3}$} & \multicolumn{2}{c}{$\mathbf{2 0 0 9}$} & \multicolumn{2}{c}{$\mathbf{2 0 1 3}$} \\
\cline { 2 - 7 } Land cover class & A (ha) & A (\%) & A (ha) & A (\%) & A (ha) & A (\%) \\
\hline MSF & 2021,76 & 17,38 & 1965,15 & 16,89 & 2011,95 & 17,29 \\
ESF & 923,85 & 7,94 & 1217,52 & 10,46 & 1027,98 & 8,83 \\
P & 7017,11 & 60,31 & 7298,63 & 62,72 & 6166,07 & 52,99 \\
PST & 1080,99 & 9,29 & 573,39 & 4,93 & 1618,83 & 13,91 \\
WA & 160,47 & 1,38 & 122,58 & 1,05 & 340,83 & 2,93 \\
GO & 410,49 & 3,53 & 437,67 & 3,76 & 446,85 & 3,84 \\
UA & 21,33 & 0,18 & 21,06 & 0,18 & 23,49 & 0,20 \\
\hline
\end{tabular}

Legend: MSF, Mid successional forest; ESF, Early successional forest; P, Pasture; PST, Pasture with shrubs and trees; WA, Water; GO, Geological outcrop; UA, Urban area.

More than $30 \%$ of the total MSF area are large forest remnants, i.e., forest patches with more than 100 ha (Figure 3A). About 70\% of the MSF patches were smaller than 10 ha (Figure 3B). No ESF patches larger than 100 ha were identified (Figure 3C), except for a single patch in 2009 that covered about $10 \%$ of the total class area. More than $80 \%$ of the ESF patches presented less than 10 ha (Figure 3D).

The areas of the MSF patches are consistently larger than those of ESF $(2003$ : $W=5954, p<0.001 ; 2009$ : $\mathrm{W}=6556, \mathrm{p}=0.013 ; 2013$ : $\mathrm{W}=6087, \mathrm{p}<0.001$ ) (Figure 4A), the size of these areas did not vary over time (ESF: $\mathrm{chi}^{2}=1.33$, g.l=2, $\mathrm{p}=0.515$; MSF: $\mathrm{chi}^{2}=0.16, \mathrm{~g} . \mathrm{l}=2, \mathrm{p}=0.923$ ) and the total area of MSF remained around $17 \%$ of landscape cover. In addition, no difference in the area of the largest MSF patch of the landscape (LFPI=3.1\%) was 
identified between the three years. The median NND was $67 \mathrm{~m}$ in all years, with no significant difference between them (MSF: $\operatorname{chi}^{2}=0.26$, g.l=2, p=0.879; ESF: chi² $^{2}=1.67$, g.l=2, p=0.434).
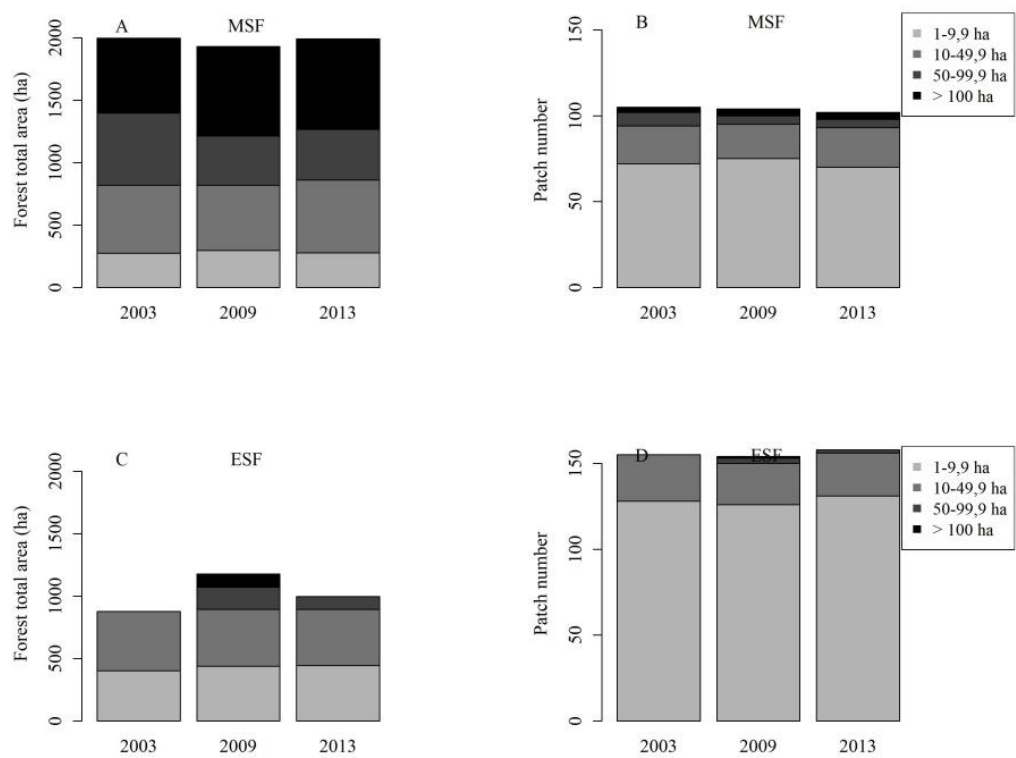

Figure 3. Class distribution of total area (A, C) and the number of patches (B, D) of mid successional forests (A, B) and early successional forests (C, D) from the catchment of Cajú and São Sebastião do Alto SHPs, in the mountainous region of the State of Rio de Janeiro state, in the years 2003, 2009 and 2013.

Figura 3. Distribuição por classe de tamanho da área total $(\mathrm{A}, \mathrm{C})$ e do número $(\mathrm{B}, \mathrm{D})$ de fragmentos de floresta em estágio médio de sucessão (A, B) e floresta em estágio inicial de sucessão $(C, D)$ da microbacia hidrográfica das PCH's Cajú e São Sebastião do Alto, na região serrana do estado do Rio de Janeiro, para os anos de 2003, 2009 e 2013.
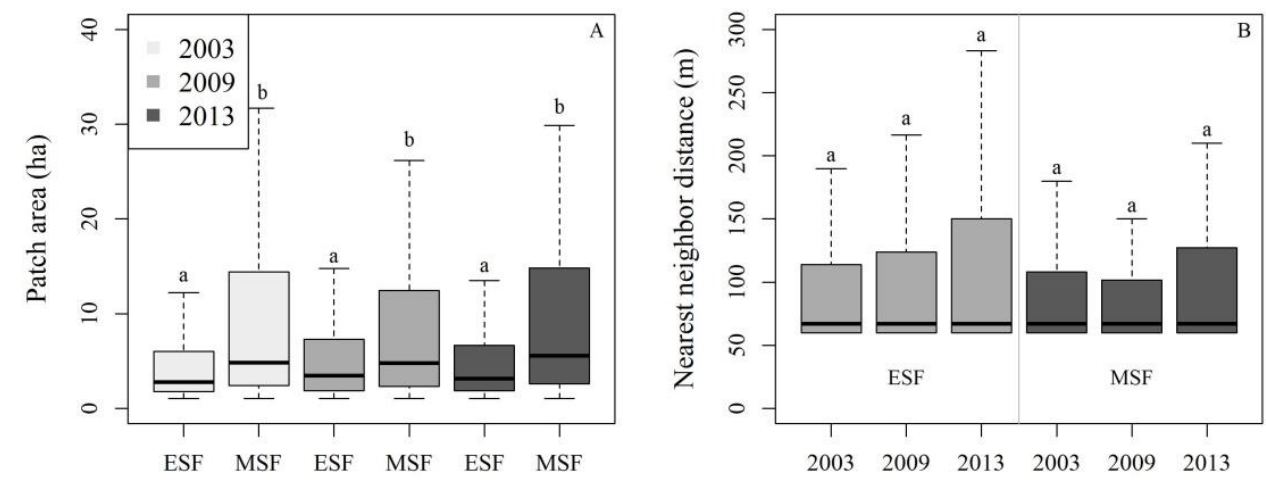

Figure 4. Boxplots for landscape metrics: Patch area (A) and nearest neighbor distance (B), by forest type (MSF: mid successional forest, ESF: early successional forest) in the years 2003, 2009 and 2013, in the catchment of Cajú and São Sebastião do Alto SHPs, mountainous region of the State of Rio de Janeiro. Only forest patches larger than 1 ha were considered for this analysis. Different letters represent significant differences between forest types (A) or between years (B), at 5\% of significance.

Figura 4. Boxplots das métricas, área dos fragmentos (A) e distância do fragmento mais próximo (B), por tipo de floresta (MSF: floresta em estágio médio, ESF: floresta em estágio inicial) e por ano (2003, 2009 e 2013), na microbacia hidrográfica dos reservatórios hídricos das PCH’s Cajú e São Sebastião do Alto, na região serrana do estado do Rio de Janeiro. Foram considerados apenas os fragmentos com mais de 1ha. Letras diferentes representam diferença significativa entre os tipos de floresta (A) ou entre os anos (B), a 5\% de significância. 


\section{Permanent Preservation Area}

There was no loss of native forest cover due to flooding of the reservoirs since more than $90 \%$ of this area was already covered by pasture in 2009, just before the construction of the reservoirs (Table 2). The losses in forest cover were observed between 2003 and 2009 (Table 3), before the damming of the Grande river and construction of the Small Hydroelectric Plants (SHP's), while the area pasture with shrubs and trees increased more than 50\% in the PPA.

Table 2. Total Area (ha and \%) for each land cover class flooded by the reservoirs of Cajú and São Sebastião do Alto SHPs, in the mountainous region of the State of Rio de Janeiro.

Tabela 2. Área (ha) e proporção (\%) de cada classe de cobertura da terra que foi alagada pela construção dos reservatórios hídricos das PCH's Cajú e São Sebastião do Alto, na região serrana do estado do Rio de Janeiro.

\begin{tabular}{ccc}
\hline Land cover class & A (ha) & $\mathbf{A}(\boldsymbol{\%})$ \\
\hline MSF & 0,27 & 0,10 \\
ESF & 9,36 & 3,49 \\
P & 242,55 & 90,47 \\
PST & 15,75 & 5,87 \\
GO & 0,18 & 0,07 \\
\hline Total & 268,11 & 100,00 \\
\hline
\end{tabular}

Legend: MSF, Mid successional forest; ESF, Early successional forest; P, Pasture; PST, Pasture with shrubs and trees; GO, Geological outcrop.

Table 3. Area (A) per land cover class in the Permanent Preservation Area of Cajú and São Sebastião do Alto SHPs water reservoirs, in the mountainous region of the State of Rio de Janeiro in the years 2003, 2009 and 2013.

Tabela 3. Área (A) por classe de cobertura da terra da Área de Preservação Permanente dos reservatórios hídricos das PCH's Cajú e São Sebastião do Alto, na região serrana do estado do Rio de Janeiro, para os anos 2003, 2009 e 2013.

\begin{tabular}{cccc|cc|cc}
\hline & \multicolumn{3}{c|}{$\mathbf{A}(\mathbf{h a})$} & \multicolumn{2}{c|}{$\mathbf{( 2 0 0 9 - 2 0 0 3 )}$} & \multicolumn{2}{c}{$(\mathbf{2 0 1 3 - 2 0 0 9 )}$} \\
\cline { 2 - 8 } Land cover class & $\mathbf{2 0 0 3}$ & $\mathbf{2 0 0 9}$ & $\mathbf{2 0 1 3}$ & $\boldsymbol{\Delta} \mathbf{( h a )}$ & $\boldsymbol{\Delta} \mathbf{( \% )}$ & $\boldsymbol{\Delta} \mathbf{( h a )}$ & $\boldsymbol{\Delta} \mathbf{( \% )}$ \\
\hline MSF & 7,60 & 4,40 & 5,62 & $-3,19$ & $-42,05$ & 1,22 & 27,70 \\
ESF & 23,63 & 15,47 & 13,49 & $-8,16$ & $-34,53$ & $-1,98$ & $-12,79$ \\
P & 307,00 & 298,96 & 240,65 & $-8,04$ & $-2,62$ & $-58,31$ & $-19,50$ \\
PST & 14,78 & 22,43 & 23,51 & 7,65 & 51,73 & 1,08 & 4,82 \\
GO & 1,68 & 1,81 & 3,24 & 0,14 & 8,10 & 1,43 & 79,10 \\
\hline Total & 354,69 & 343,07 & 286,52 & $-11,61$ & $-3,27$ & $-56,56$ & $-16,49$ \\
\hline
\end{tabular}

Legend: $\Delta$ (ha): difference of area (ha) between years, $\Delta(\%)$ : percentage of $\Delta$ in relation to the area (ha) of the earliest year. MSF, Mid successional forest; ESF, Early successional forest; P, Pasture; PST, Pasture with some shrubs and trees; GO, Geological outcrop.

\section{DISCUSSION}

The catchment of Cajú and São Sebastião do Alto SHP's reservoirs is predominantly covered by pasture, with several small and isolated patches of mid and early successional forest. The predominance of pasture in the landscape reflects the region's main economic activity: extensive livestock production, which was responsible for forest fragmentation and degradation prior to the construction of the Grande river SHP's and respective reservoirs. The northern and northwestern regions of the State of Rio de Janeiro are among the most critical areas for conservation in the State, where major losses in forest cover have been registered, usually related to agriculture and livestock production from 1995 to 2000 (DRZ GEOTECNOLOGY AND CONSULTANCY, 2012).

The MSF areas in the catchment suffered few changes during the evaluated period. Adding all MSF and ESF patches, the forests occupy 25 to $27 \%$ of the catchment area, a little bellow the fragmentation threshold (30\%), above which financial investments in restoration are optimized (TAMBOSI et al., 2014). Thus, according to the landscape resilience, it falls under an ideal situation for restoration (which emphasizes the environmental and financial cost-benefit ratio), compared with both well-preserved landscapes, with almost no marginal restoration benefits, or with degraded landscapes, with high financial costs (TAMBOSI et al., 2014). Also, from a

FLORESTA, Curitiba, PR, v. 50, n. 4, p. 1808 - 1817, out/dez 2020.

Cardinelli, L. S. et.al.

ISSN eletrônico 1982-4688

DOI: 10.5380/rf.v50 i4. 65893 
conservation perspective, knowledge on the forest distribution by the size of patches may be more important than the overall coverage in the landscape (ARROYO-RODRIGUEZ et al., 2009). That is, the ratio between small patches and forest remnants to the total area of forest is an excellent indicator of the conservation status of a given site, directly addressing the ecological diversity and functions and their capacity to provide environmental services (DIXO et al., 2009; MAGNAGO et al., 2015).

Large forest remnants perform ecological key functions, such as the providing of habitat and resources for local fauna, especially for large mammals, and occupy the largest portion of the overall area of mid successional forests. In the studied area, they are often associated with the outcrops and steeper slopes (verified by personal observation and map reading). These environments present a very low potential for agriculture, which is the main reason for its preservation throughout the years in area and shape. In general, the fragmentation of tropical forests occurred in a highly selective manner (not randomly), resulting in a mosaic constituted by a few large remnants mostly located on low fertility soils, steep terrain, in the middle of a human-altered matrix over the most fertile soils of the area, on flat terrains which are more suitable for mechanization (ARROYO-MORA et al., 2005).

On the other hand, the forest patches are mostly small, up to 10 ha. The correlation between the reduction of native vegetation patches and the decline of biodiversity is often discussed by researchers, supported by the classical specimen-area relationship (EWERS; DIDHAM, 2006), and by the Theory of Island Biogeography (MACARTHUR; WILSON, 1967) adapted for terrestrial ecosystems (MAGNAGO et al., 2015). The fragmentation of the Atlantic Forest has been leading towards a decline in the number of plant and animal species, especially those threatened with extinction (DIXO et al., 2009; LIMA et al., 2015; MAGNAGO et al., 2015; MARTENSEN et al., 2012). Many researchers highlight the importance of small patches for maintaining biodiversity at the landscape scale, as they constitute the bulk of the remaining areas of the Atlantic Forest (SOS MATA ATLANTICA; INPE, 2014), and are therefore strategic for the restoration of the biome. Also, these patches are known to maintain high taxonomic and functional richness (ARROYO-RODRIGUEZ et al., 2009; JOLY et al., 2014; MAGNAGO et al., 2015).

Along with the patches' size, the degree of isolation is also of great importance to assess the conservation status and ecological potential in the landscape context. In the studied area, most forest patches are only a few tens of meters away from the nearest similar one and can function as ecological stepping stones, enabling gene flow between the patches by increasing the transit of pollinator and dispersing animals and so, diminishing the negative effects of isolation (PETERSON; CARSON, 2008).

On average, MSF patches are three times larger than those of ESF in all the studied years, with no significant variation in the area over time. This includes the largest MSF patch in the landscape (366.9 ha), which did not show any size variation during the 10-year interval evaluated in this study. The forest cover evolution suggests that the succession stage of the forest patches do not correspond to the actual age. In fact, many patches did not display changes in area or succession stage over a decade. The main environmental variables influencing succession rate and forest cover dynamics comprise topographic position, topographic gradient, solar radiation, soil type, history of land use and occupation, and proximity to native vegetation, urban area or roads (ARROYOMORA et al., 2005; REZENDE et al., 2015). In the case of this study, proximity to outcrops and, indirectly, to low agricultural capacity, could be included as determining factors in the dynamics of forest cover of the landscape.

The predominance of pasture within the flooded area resulting from the construction of the Caju and São Sebastião do Alto SHPs indicates an acceptable environmental impact of the project, mostly constricted with the flooded area. A greater environmental impact in the region is the conversion of much of the native vegetation to agricultural use, fragmenting the forest, which occurred long before the construction of the SHPs.

The results of the land cover dynamics in the Permanent Preservation Areas for the 2003-2009 periods suggest noncompliance with the forestry legislation of the time, as the delimited PPA was not covered with riparian forests. In fact, the few riparian fragments existing in 2003 no longer appeared in 2009, as a result of agricultural activity in the region. Significant advances in the restoration of the PPAs were observed after the construction of the SHPs in 2009, culminating with an increase in forest cover of about $25 \%$ in 2013. Reforestation with regional native species, along with fire and livestock management, has led to this result, enabling the growth of seedlings and stimulating natural regeneration.

The result obtained in the PPA can be attributed to various environmental factors that enhance natural regeneration in this catchment, such as the presence of neighboring forest remnants, which act as a seed source for degraded areas. Furthermore, the soils in the region are eutrophic (DRZ GEOTECNOLOGY AND CONSULTING, 2012; PROJETO RADAMBRASIL, 1983), namely in the lowlands and on the water reservoirs banks, i.e., they have high levels of nutrients for primary growth, an uncommon situation for most soils in Brazil. Finally, the proximity of water bodies favors the arrival of propagules by hydrochory or zoochory and contributes to soil humidity facilitating the restoration process in the PPA of the water reservoirs of the Cajú and São Sebastião do Alto SHP's.

FLORESTA, Curitiba, PR, v. 50, n. 4, p. 1808 - 1817, out/dez 2020. 
Secondary forest regeneration has been observed for other municipalities in the northern mountainous region of Rio de Janeiro, such as Trajano de Morais, whose forest cover regain 15\% in 40 years (REZENDE et al., 2015). According to the authors, the main causes of this increase were the rural exodus and consequent land abandonment. Such factors are often associated with forest cover growth in several other regions of Brazil (MARTINS et al., 2014; SANTOS et al., 2012) and in other Latin American countries (ARROYO-MORA et al., 2005).

\section{CONCLUSIONS}

- There have been no significant advances in deforestation or forest regeneration, with few changes in the forest cover over the last ten years in the catchment area.

- The catchment is predominantly covered by pasture, with few large mid successional forest remnants and many small forest patches, which showed no significant changes in size or degree of isolation over the studied period.

- An increase in the forest cover inside the PPA was identified between 2009 and 2013, mainly associated with the exclusion of cattle by enclosure and reforestation initiatives, with native species.

- This study demonstrated that this catchment, in the northern mountainous region of Rio de Janeiro, presents a high natural regeneration potential and highlights the importance of assisted natural regeneration as a relatively low-cost strategy towards an effective forest restoration of landscapes with similar environmental conditions.

\section{ACKNOWLEDGMENTS}

The authors would like to thank the National Research Council - CNPq for the first author's master's grant and the third author's productivity grant and the companies Energisa and Brookfield Energia Renovável for the financial support of the project.

\section{REFERENCES}

ALVARES, C. A.; STAPE, J .L.; SENTELHAS, P. C. Köppen's climate classification map for Brazil. Meteorologische Zeitschrift, v. 22, n. 6, p. 711-728, 2013.

ARROYO-MORA, J. P.; SÁNCHEZ-AZOFEIFA, G. A.; RIVARD, B.; CALVO, J. C.; JANZEN, H. Dynamics in landscape structure and composition for the Chorotega region, Costa Rica from 1960 to 2000. Agriculture, Ecosystems and Environment, v. 106, n. 1, p. 27-39, 2005.

ARROYO-RODRIGUEZ, V.; PINEDA, E.; ESCOBAR, F.; BENITEZ-MALVIDO, J. Value of Small Patches in the Conservation of Plant-Species Diversity in Highly Fragmented Rainforest. Conservation Biology, v. 23, n. 3, p. 729-739, 2009.

BRASIL. Lei n. 4771, de 15 de setembro de 1965. Institui o novo Código Florestal (Revogada pela Lei n. 12651, de 25 de maio de 2012). Diário Oficial da União, Brasília, DF, 1965. Disponível em: <http://www.planalto.gov.br/ ccivil_03/leis/14771.htm>. Acesso em: 18 mai. 2020.

BRASIL. Lei n. 12651, de 25 de maio de 2012. Dispõe sobre a proteção da vegetação nativa; altera as Leis nos 6.938, de 31 de agosto de 1981, 9.393, de 19 de dezembro de 1996, e 11.428, de 22 de dezembro de 2006; revoga as Leis nos 4.771, de 15 de setembro de 1965. Diário Oficial da União, Brasília, DF, 25 de maio de 2012. Disponível em: <http://www.planalto.gov.br/ccivil_03/_ato2011-2014/2012/lei/112651.htm>. Acesso em: 4 out. 2016.

DIXO, M.; METZGER, J. P.; MORGANTE, J. S.; ZAMUDIO, K. R. Habitat fragmentation reduces genetic diversity and connectivity among toad populations in the Brazilian Coastal Forest. Biological Conservation, v. 142, p. $1560-1569,2009$.

DRZ GEOTECNOLOGIA E CONSUlTORIA. Plano municipal de saneamento básico: Plano regional de saneamento com base municipalizada das modalidades água, esgoto e drenagem urbana. Santa Maria Madalena, RJ, 2012, 147p.. Disponível em: <http://www.cbhriodoisrios.org.br/saneamento/smmadalena/DiagnosticoSetorial.pdf> Acesso em 1 de ago. 2017

EWERS, R. M.; DIDHAM, R. K. Confounding factors in the detection of species responses to habitat fragmentation. Biological Reviews, v. 81, p. 117-142, 2006. 
GONGALTON, R. G.; GREEN, K. A. Assessing the accuracy of remotely sensed data - principles and practices. $2^{\mathrm{a}}$ ed. [s.1.] CRC Press LLC, 2009.

HOLL, K. D.; AIDE, T. M. When and where to actively restore ecosystems? Forest Ecology and Management, The Ecology and Ecosystem Services of Native Trees: Implications for Reforestation and Land Restoration in Mesoamerica. v. 261, n. 10, p. 1558-1563, 2011.

JOLY, C. A.; METZGER, J. P.; TABARELLI, M. Experiences from the Brazilian Atlantic Forest: ecological findings and conservation initiatives. New Phytologist, Tansley reviews. v. 204, p. 459-473, 2014

LEITE, M. S.; TAMBOSI, L. R.; ROMITELli, I.; METZGER, J. P. Landscape Ecology Perspective in Restoration Projects for Biodiversity Conservation: a Review. Brazilian Journal of Nature Conservation, v. 11, n. 2, p. 108-118, 2013.

LIMA, R. A. F.; MORI, D. P.; PITTA, G.; MELITO, M. O.; BELlO, C.; MAGNAGO, L. F. S.; ZWIENER, V. P.; SARAIVA, D. D.; MARQUES, M. C. M.; OLIVEIRA, A. A.; PRADO, P. I. How much do we know about the endangered Atlantic Forest? Reviewing nearly 70 years of information on tree community surveys. Biodiversity and Conservation, v. 24, n. 9, p. 2135-2148, 2015.

MACARTHUR, R. H.; WILSON, E. O. The theory of island biogeography. Princeton: Princeton University Press, 1967, 224p.

MAGNAGO, L. F. S.; MAGRACH, A.; LAURANCE, W. F.; MARTINS, S. V.; MEIRA-NETO, J. A. A.; SIMONELLI, M.; EDWARDS, D. P. Would protecting tropical forest fragments provide carbon and biodiversity co-benefits under REDD+? Global Change Biology, v. 21, n. 9, p. 3455-3468, 2015.

MARTENSEN, A. C.; RIBEIRO, M. C.; BANKS-LEITE, C.; PRADO, C. I. O.; METZGER, J. P. Associations of Forest Cover, Fragment Area, and Connectivity with Neotropical Understory Bird Species Richness and Abundance. Conservation Biology, v. 26, n. 6, p. 1100-1111, 2012.

MARTINS, S. V.; SARTORI, M.; RAPOSO-FILHO, F. L.; SIMONELLI, M.; DADALTO, G.; PEREIRA, M. L.; SILVA, A. E. S. Potencial de regeneração natural de florestas nativas nas diferentes regiões do estado do Espírito Santo. Vitória: CEDAGRO - Centro de Desenvolvimento do Agronegócio, 2014, 102p.

METZGER, J. P.; BRANCALION, P. H. S. Challenges and opportunities in applying a Landscape Ecology Perspective in Ecological Restoration: a Powerful Approach to Shape Neolandscapes. Brazilian Journal of Nature Conservation, v. 11, n. 2, p. 103-107, 2013.

PETERSON, C. J.; CARSON, W. P. Processes constraining woody species succession on abandoned pastures in the tropics: on the relevance of temperate models of succession. In: CARSON, W. P.; SCHNITZER, S. A. (Eds.). . Tropical Forest Community Ecology. [s.1.] Blackwell Publishing Ltd., 2008. p. 363-383.

PROJETO RADAMBRASIL. Folhas SF. 23/24 Rio de Janeiro/Vitória: geologia, geomorfologia, pedologia, vegetação e uso potencial da terra. Rio de Janeiro: Levantamento de recursos naturais, 1983, 775p..

REZENDE, C. L.; UEZU, A.; SCARANO, F. R.; ARAUJO, D. S. D. Atlantic Forest spontaneous regeneration at landscape scale. Biodiversity and Conservation, v. 24, n. 9, p. 2255-2272, 2015.

SANTOS, A. R.; ALMEIDA JUNIOR, H. C. DE; EUGENIO, F. C. Evolução da cobertura florestal no município de Santa Maria de Jetibá - ES. Floresta e Ambiente, v. 19, n. 3, p. 5296-307, 2012.

SONG, C.; WOODCOCK, C. E.; SETO, K. C.; LENNEY, M. P.; MACOMBER, S. A. Classification and change detection using Landsat TM Data: When and how to correct atmospheric effects? Remote Sensing of Environment, v. 75, n. 2, p. 230-244, 2001.

SOS MATA ATLÂNTICA; INPE. Atlas dos remanescentes florestais da Mata Atlântica: período $2012-2013$. São Paulo, 2014, 61p. Disponível em: <http://mapas.sosma.org.br/site_media/download/atlas_20122013_relatorio_tecnico_2014.pdf>.Acesso em 1 de ago 2016.

TAMBOSI, L. R.; MARTEnSEN, A. C.; RIBEIRO, M. C.; METZGER, J. P. A Framework to Optimize Biodiversity Restoration Efforts Based on Habitat Amount and Landscape Connectivity. Restoration Ecology, v. 22, n. 2, p. 169-177, 2014. 